DOI:10.17951/h.2021.55.1.85-99

\begin{tabular}{lcl}
\hline \multicolumn{1}{c}{ A N N A L E S } \\
UNIVERSITATIS MARIAE CURIE-SKŁODOWSKA \\
LUBLIN - POLONIA \\
VOL. LV, 1 & SECTIOH H \\
\hline
\end{tabular}

\author{
JERZY WĘCŁAWSKI \\ jerzy.weclawski@poczta.umcs.lublin.pl \\ University of Maria Curie-Skłodowska. Faculty of Economics \\ 5 Maria Curie-Skłodowska Sq., 20-031 Lublin, Poland \\ ORCID ID: https://orcid.org/0000-0003-0870-5083
}

\title{
The Role of the Family in Polish Family Enterprises
}

Keywords: family firms; family business governance; family business management; types of family businesses

JEL: D23; G32; G34

How to quote this paper: Węcławski, J. (2021). The Role of the Family in Polish Family Enterprises. Annales Universitatis Mariae Curie-Skłodowska, sectio H-Oeconomia, Vol. 55, No. 1.

\begin{abstract}
The sector of family enterprises is smaller in Poland than in countries with a long tradition of market economies. A large part of the family business is owned by the generation of their owners. The purpose of this article is to define the role of the family in ownership, management and supervision in family enterprises. Empirical research was conducted in 2014 based on the CATI questionnaire. The research covered a randomly selected nationwide sample of seven hundred and fifty-eight medium and large enterprises, of which three hundred and ninety-six entities were qualified on the basis of the SFI as family enterprises. The empirical data were evaluated based on the analysis of the structure of the population, the analysis of interdependencies and cluster analysis. The results of the research allowed formulation of three conclusions. Firstly, in the majority of enterprises, the family of owners has a dominant share in equity capital. Secondly, the company managements are relatively narrow and dominated by people from the generation of founders. Thirdly, supervisory bodies are found in a few enterprises and are made up in large part by the owners' family members. This characteristic of Polish family enterprises leads to a generalizing statement that as family enterprises, they are mostly in the initial stage of development.
\end{abstract}




\section{Introduction}

The reactivation of family enterprises in Poland took place at the end of the 1980s. Their importance is systematically growing, but it is not as large as in the countries with the continuity of the market economy. Most enterprises are still in the hands of the first generation of owners. The question arises, how does this translate into ownership structures and company management? It can be assumed that they show a number of differences in relationship to family enterprises from these countries. Therefore, the starting point refers to the results of research presented in the literature on the subject of countries with developed sectors of family enterprises. The purpose of the article is to define the role of the family in Polish family enterprises. The analysis focuses on issues of ownership, management and supervision. The research covered medium and large enterprises because small companies have a slight dispersion of property and a simplified organizational structure. Empirical materials come from empirical research on ownership and corporate governance in Polish family enterprises. ${ }^{1}$

\section{The importance of family enterprises in the Polish economy}

The economic importance of family enterprises is very large in a number of countries. For example, in Austria or Germany, i.e. countries with which Poland has a number of cultural, legal and economic similarities, they account for approximately $90 \%$ of the total number of enterprises, employ $60-70 \%$ of all employees and carry out $50-60 \%$ of turnover (Anteile..., 2018; Familienunternehmen in Österreich ..., 2013). Determining the importance of family enterprises in the Polish economy is difficult due to the lack of official statistical data and a clear definition of a family enterprise. Therefore, the available data are estimates. According to a study conducted in 2016 in Poland, $27 \%$ of enterprises can be counted as family based on the criterion that the family has a majority stake and at least one family member is involved in management, as defined by the European Commission, Enterprise and Industry Directorate General (Overview..., 2009). These enterprises generate 18\% of GDP (Firma ..., 2016).

\section{Literature review}

A significant number and the accompanying strong diversity of family enterprises make it difficult to create one universally accepted definition. Individual authors propose different criteria distinguishing a family enterprise from subjective ones, such as

\footnotetext{
1 Polish National Science Centre Project No. 2012/07/B/HS4/00455 “Corporate governance, ownership structure and other financial issues of family enterprises in Poland and Austria - a comparative analysis".
} 
perception by the owners themselves as a family enterprise (Sten, 2006), declarative, how to manage family values (Aronoff $\&$ Ward, 2011) and family having a decisive influence on the enterprise (Wimmer, Domayer, Oswald, \& Vater, 2018) to rational criteria such as family participation in the capital, management board and supervisory board (Zellweger, Halter, \& Frey, 2006; Astrachan, Klein, \& Smyrnios, 2002). In more developed approaches, the family is also shaped by the normative foundations of the enterprise, the definition of its mission and its scope of activity (Scherer, Blanc, Kormann, Groth, \& Wimmer, 2012). One of the characteristic features of family enterprises is the intergenerational transfer of values. Some researchers even consider a family business as one in which at least two generations of one family have a significant impact on the company's goals and policy (Donnelley, 2002).

The essence of a family enterprise is that it consists of three systems: the family, the enterprise and the owners (Gersick, McCollom Hampton, \& Lansberg, 1997). Key factors for determining the relationships between these systems are ownership and participation in management (Simon (Ed.), 2011). Each of the systems forming a family enterprise follows a different logic and goals (Pieper \& Klein, 2007). The family of owners strives not only to achieve financial goals, such as maximizing profits or increasing the value of the company, but also non-financial ones (Astrachan \& Jaskiewicz, 2008; Pernsteiner \& Węcławski (Eds.), 2016). The latter group includes persistence of the enterprise, maintaining independence from third parties, maintaining reputation, promoting family values and creating trust from stakeholders (Achleitner, Bock, Braun, Schraml, \& Welter, 2010). Both of these systems interact with each other, with the family's influence on the enterprise being more or less formal depending on the ownership structure and the structure of management that exists in it (Mandl, 2008). This system is complicated by the fact that in companies belonging to a family, the co-owners and managers may be outside of the family (Klein, 2010).

In the development of family enterprises, it is possible to identify several phases in which there is a change in the relationship between the family system and the enterprise system (Gersick, et al., 1997; Koładkiewicz, 2015). In the initial period of existence of the enterprise, both systems are largely identical. In a small enterprise based on the capital of the founders, they usually deal with the direct management of the company and exercise control over it (Klein, 2010). As the company develops, family and enterprise systems are increasingly separated, property is diversified as a result of enlarging the family or accepting co-owners from outside the family, the scope of direct family involvement decreases, organizational complexity grows and the need to implement professional management mechanisms and controlling operations increases (Schweinsberg \& Koenen, 2010). This development cycle is accompanied by a change in the role of the family in the enterprise and the way of influencing it.

The basis for determining the role of the family in the enterprise is property rights (Gersick, et al., 1997; Hennerkes, 1998). The strong concentration of property in the hands of the family allows it to achieve goals such as the long-term existence and development of the company. This is facilitated by the direct management by 
the owners, because the incentive systems used for external managers cause them to focus on ensuring the effectiveness of the company in the medium term. In contrast, non-family investors providing the capital are focused on a short-term perspective of profits (De Visscher, 2004).

A relatively large share of equity in total capital is also characteristic for family enterprises. Individual authors provide different values of equity ratios, but in many family enterprises, it ranges from 30-40\% (Achleitner, Schraml, \& Klöckner, 2008; Prym, 2011). This allows them to maintain the economic independence of the company, but may limit the possibilities of its development. Solutions to this problem are sought in self-financing - the owners limit the payment of dividends and allocate liquid funds to finance its development (Scherer, Blanc, Kormann, Groth, \& Wimmer, 2012). At the same time, owners' families put "patient capital" at the disposal of enterprises as a long-term financial capital not threatened with quick withdrawal (Sirmon \& Hitt, 2003). Owners are exposed as a result of such a policy to the risk of losing a significant part of this property in the event of bankruptcy of the company, which encourages them to be more cautious in running the business. One of the consequences of risk aversion is personal involvement of the owners in managing the enterprise or participation in supervisory boards (Scherer, et al., 2012).

In small family enterprises, the structures of corporate governance are poorly developed. There is a strong concentration of property in the hands of the family, and its representatives exercise direct control over the company. This control takes the form of family members taking managerial positions in the company and participating in its operational management. The scope of family participation in operational company management is perceived differently by individual authors (Wiechers, 2006). However, it is clear that the need to engage with highly qualified external managers grows with the size of the enterprise (Winkeljohann \& Kellersmann, 2008; Klein, 2010). At the same time, they may include shares in an enterprise or only employees. Inclusion of managers into the group of shareholders leads to the dispersion of ownership and the limitation of family influence on them (Achleitner, et al., 2010).

The succession is a specific feature of a family enterprise that takes place both in the sphere of ownership and management. With the passing of another generation, its ownership structure and method of managing it are dispersed (Kenyon-Rouvinez \& Ward, 2005; Hartley \& Griffith, 2009). The dispersion of ownership in the first generation is usually small, but in the second and later generations, the number of co-owners increases, and some of them do not take part in direct management (Scherer, et al., 2012).

In a family enterprise, there may be a conflict of interest between the various participants (Simon, Wimmer, \& Groth, 2005; Hepperle, 2011). In particular, these may be conflicts between family employees employed in the company and non-employed representatives of different generations of co-owners and between the owners and the management staff from outside the family. In the latter case, the divergence of interests of managers and families may result from the fact that managers take up 
shares in an enterprise or act only as managers (Hiebl, 2012). Securing the interests of the family in the enterprise and mitigating the conflicts occurring in it serve to adopt formal principles of its functioning. They may take the form of a company's constitution or agreements (Mutter, 2011; Scherer, et al., 2012). The existence of corporate governance structures in family enterprises is also necessary to ensure efficient succession (Koładkiewicz, 2015).

The variety of family enterprises prompts their classification on the basis of various criteria. From the point of view of the subject of this study, it should be pointed out that these classifications are built on the basis of the factors determining the impact of the family on the enterprise, such as family participation in equity, management and control bodies, the scope of delegating competences to non-family managers (Astrachan \& Shanker, 2003) or the goals of the activity - "family first", "management first", "ownership first" (Poza, 2010).

\section{Research hypotheses}

Guided by the research of other authors, it was assumed that participation in ownership, management and control is of fundamental importance for determining the role of the family in family enterprises. At the same time, due to the relatively short period of existence of family enterprises in Poland, it was assumed that they are strongly influenced by the family. Based on these assumptions, the following research hypotheses were formulated:

H1: In family enterprises, families have a dominant share in ownership.

$\mathrm{H} 2$ : There is a strong concentration of management in family enterprises by the owners' families.

H3: The corporate governance bodies are underdeveloped in family enterprises.

\section{Research sample and research methods}

Empirical research was carried out in 2014 on a randomly selected nationwide sample of enterprises with the CATI techniques. Interviews were conducted with business owners and managers. The research covered medium and large enterprises (employment of over forty-nine employees), assuming that the analysed phenomena and processes are more developed and diversified in them. The research sample consisted of seven hundred and fifty-eight entities, of which three hundred and ninety-six were identified as family enterprises. The classification of family businesses was made on the basis of the Substantial Family Influence (SFI) index. It assumes that a family enterprise employs at least two family members, at least one of whom has a significant impact on management, while the family maintains majority ownership in the capital (Klein, 2000). 
Descriptive analysis of the tested sample allows identifying the following characteristics. Most enterprises took the form of a LTD company (61.3\%), and less often, they were general partnerships or limited partnerships $(24.7 \%)$, joint-stock companies $(5.6 \%)$ or sole trading $(8.4 \%)$. The remaining forms were sporadic. Only three companies were listed on the stock exchange.

Enterprises came from various industries. Industrial processing dominated (57.1\%), followed by construction (13.8\%), trade (6.2\%), accommodation and catering (2.6\%), financial and insurance activities $(2.6 \%)$ and health care $(1.9 \%)$.

The majority of the surveyed enterprises (93\%) employed from 50 to 249 employees. The rest employed over 249 people. The average employment was 114 employees. However, the diversification of enterprises in terms of revenues was as follows: $7.8 \%$ had annual revenues up to PLN 5 million, $67.4 \%$ in the range of PLN 5-50 million, $21.0 \%$ in the range of PLN 50-200 million, and 3.8\% over PLN 200 million. Based on the classification adopted by the European Union (Commission..., 2003), medium-sized enterprises were dominant in terms of employment, but the majority were small in terms of revenues.

The description and analysis of the collected statistical material were carried out based on analysis of the group structure, analysis of interdependencies and cluster analysis.

\section{Results of the research}

As part of the research, a comparison of the company's own assessment was carried out to determine whether they are classified as family companies on the basis of the SFI index. The sample of enterprises recognized as family based on this indicator amounted to three hundred and ninety-six companies. The question of whether they are family enterprises was answered positively by three hundred and thirty-eight of them. According to the SFI index, three hundred and nineteen of them (94.4\%) should be considered family businesses. The level of proper self-identification of companies as family thus was very high.

The return to the market economy in Poland in 1989 was associated with significant activity in establishing enterprises, including family ones. This is also indicated by the age structure of the surveyed enterprises. Most of them was founded in the 1990s. Their average age was 21 years. These results are confirmed by other studies, which indicate that $96 \%$ of family enterprises in Poland are under thirty-one years old (Firma ..., 2016) (Table 1). 
Pobrane z czasopisma Annales H - Oeconomia http://oeconomia.annales.umcs.pl Data: 26/04/2023 14:01:45

THE ROLE OF THE FAMILY IN POLISH FAMILY ENTERPRISES

Table 1. Age structure of enterprises

\begin{tabular}{|l|c|}
\hline \multicolumn{1}{|c|}{ The age of enterprises $(\mathrm{n}=392)$} & Participation $(\%)$ \\
\hline Below 10 years & 8.4 \\
\hline $10-19$ years & 39.0 \\
\hline 20-29 years & 44.6 \\
\hline Above 30 years & 8.0 \\
\hline
\end{tabular}

Source: Author's own study based on the results of the survey.

The results of the research show that in $31.2 \%$ of enterprises, representatives of the second generation appeared as co-owners or took over the company. However, due to the above-mentioned relatively short period of reactivation of family enterprises, their percentage in the third and subsequent generations is insignificant (see Table 2).

Table 2. Ownership structure according to the generation of shareholders

\begin{tabular}{|l|c|}
\hline \multicolumn{1}{|c|}{ Generation $(\mathrm{n}=308)$} & Participation (\%) \\
\hline First & 68.1 \\
\hline First or second & 31.2 \\
\hline Other & 0.7 \\
\hline
\end{tabular}

Source: Author's own study based on the results of the survey.

The durability of family enterprises is indicated by the fact that the vast majority of them were founded and still remain in the ownership of the same family. Such a situation occurred in $96.8 \%$ of the surveyed enterprises $(n=378)$. The rest were bought by the family from other owners.

The ownership structure was analysed in two aspects: the number of owners belonging to the family and the share of the family in equity. Ownership in the majority of surveyed family enterprises is concentrated within a small group of people. Almost one-quarter of enterprises were in the ownership of one person. In almost half of the companies, the owners were two family members. Greater dispersion of property (three and more people) took place only in less than a third of enterprises. At the same time, in the vast majority of the surveyed enterprises, family members were the only or the majority owners (see Table 3 ).

Table 3. Number of shareholders from the family in the company

\begin{tabular}{|l|c|c|c|}
\hline $\begin{array}{c}\text { Number of owners } \\
(\mathrm{n}=373)\end{array}$ & $\begin{array}{c}\text { Share of enterprises } \\
(\%)\end{array}$ & $\begin{array}{c}\text { Family participation in } \\
\text { capital }(\mathrm{n}=396)\end{array}$ & $\begin{array}{c}\text { Share of enterprises } \\
(\%)\end{array}$ \\
\hline 1 & 22.5 & $100 \%$ & 81.7 \\
\hline 2 & 46.7 & $51-99 \%$ & 15.6 \\
\hline 3 and more & 30.8 & $0-50 \%$ & 2.7 \\
\hline
\end{tabular}

Source: Author's own study based on the results of the survey. 
When assessing the concentration of property in family enterprises, it should be underscored that the research did not include small enterprises in which the dispersion of property is undoubtedly even smaller.

An expression of the desire to ensure a strong family position in the enterprise and independence from external sources of financing is, in particular, maintaining a high share of equity in total capital and the accumulation of profits. The equity ratio in a large part (38.2\%) of the family enterprises surveyed was $100 \%$, and in over $80 \%$, it was higher than $40 \%$. The high share of equity in total capital was largely a consequence of allocating a relatively small part of profits to dividend payments (see Table 4). The average dividend rate was $22.1 \%$, so in more than half of the enterprises, it was lower than the average.

Table 4. Equity and dividend rate

\begin{tabular}{|l|c|c|c|}
\hline Capital indicator $(\mathrm{n}=364)$ & Share of enterprises $(\%)$ & The dividend rate $(\mathrm{n}=350)$ & Share of enterprises $(\%)$ \\
\hline $100 \%$ & 38.2 & $100 \%$ & 9.0 \\
\hline $81-99 \%$ & 10.4 & $81-99 \%$ & 3.8 \\
\hline $61-80 \%$ & 13.3 & $61-80 \%$ & 9.6 \\
\hline $41-60 \%$ & 19.7 & $41-60 \%$ & 11.4 \\
\hline $21-40 \%$ & 13.9 & $21-40 \%$ & 15.7 \\
\hline $0-20 \%$ & 4.6 & $0-20 \%$ & 50.4 \\
\hline
\end{tabular}

Source: Author's own study based on the results of the survey.

The occurrence of various groups of stakeholders in a family of owners and in a family enterprise requires a creation of the supervisory system. The collegial composition of the governing bodies of the company allows for the development of consensus between different groups of owners and managers from outside this group and limiting conflicts of interest.

Boards in the studied group of family enterprises were relatively narrow and did not include more than three people (Table 5). However, supervisory boards existed only in eighty-five of them (22.5\%). It should be noted that none of the surveyed companies met the criterion of the number of more than twenty-five partners for the LTD company, and only $5.6 \%$ took the legal form of a joint-stock company, for which the law requires the appointment of a supervisory board. In the enterprises in which the supervisory board was appointed, it usually consisted of only three people, i.e. the minimum number required by the Code of Commercial Companies (Ustawa..., 2000). Family representatives were always, although on a different scale, represented in supervisory bodies. Occasional revision commissions have been created in family enterprises (3). At the same time, $18.8 \%$ of companies had the formalization of corporate governance in the form of a code, but in $13.4 \%$, it was the result of a voluntary decision, and in the remaining ones, it resulted from the provisions of law. 
Pobrane z czasopisma Annales H - Oeconomia http://oeconomia.annales.umcs.pl Data: 26/04/2023 14:01:45

THE ROLE OF THE FAMILY IN POLISH FAMILY ENTERPRISES

Table 5. The number of people, including family members, on the board of directors and the supervisory board

\begin{tabular}{|l|c|c|c|}
\hline \multirow{2}{*}{$\begin{array}{c}\text { Number } \\
\text { of people }\end{array}$} & \multicolumn{3}{|c|}{ Share of enterprises (\%) } \\
\cline { 2 - 4 } & \multicolumn{2}{|c|}{$\begin{array}{c}\text { Management } \\
(\mathrm{n}=392)\end{array}$} & $\begin{array}{c}\text { Board of directors } \\
(\mathrm{n}=85)\end{array}$ \\
\hline 1 & Total & including family members & Total \\
\hline 2 & 27.8 & 100.0 & 0.0 \\
\hline 3 & 33.9 & 100.0 & 0.0 \\
\hline 4 & 24.5 & 56.3 & 64.7 \\
\hline 5 & 8.2 & 50.0 & 21.2 \\
\hline Over 5 & 2.6 & 20.0 & 10.6 \\
\hline
\end{tabular}

Source: Author's own study based on the results of the survey.

Enhancing the assessment of the position of the family in the enterprise requires analysis that goes beyond only determining its share in ownership and the number of family members in the management bodies. The real power of the family depends to a large extent on its direct involvement in the day-to-day management of the company.

In the vast majority of surveyed enterprises (88.0\%), a family member was in charge of direct management as the chairman of the board. To a much lesser extent, the person responsible for finance came from the family group (36.7\%). This means that two-thirds of enterprises decided to entrust financial management to non-family professionals (see Table 6).

Table 6. Participation of family members in the management of the company

\begin{tabular}{|l|c|c|}
\hline \multicolumn{1}{|c|}{ Member of the board } & $\begin{array}{c}\text { Chairman of the board } \\
(\mathrm{n}=394)\end{array}$ & $\begin{array}{c}\text { Person responsible for finances } \\
(\mathrm{n}=330)\end{array}$ \\
\hline Family member & 88.0 & 36.7 \\
\hline Person from outside of the family & 12.0 & 63.3 \\
\hline
\end{tabular}

Source: Author's own study based on the results of the survey.

The consequence of the relatively short period of existence of family enterprises was that a significant share of their family members are from the generation of their founders (75.9\%). By summarizing the information in Tables 2 and 7, one can conclude that in the surveyed enterprises, the transfer of ownership rather than power took place to a greater extent. Representatives of the second generation received shares in enterprises, but their management remains largely in the hands of the founders. It stands that the processes of the first succession in many Polish family enterprises have not been completed. 
Pobrane z czasopisma Annales H - Oeconomia http://oeconomia.annales.umcs.pl

Data: 26/04/2023 14:01:45

JERZY WĘCŁAWSKI

Table 7. Family generation on the board

\begin{tabular}{|l|c|}
\hline \multicolumn{1}{|c|}{ Generation $(\mathrm{n}=387)$} & Participation (\%) \\
\hline 1 & 75.9 \\
\hline 1 and 2 & 16.8 \\
\hline 1,2 and 3 & 0.3 \\
\hline 2 & 6.7 \\
\hline 3 & 0.4 \\
\hline
\end{tabular}

Source: Author's own study based on the results of the survey.

In addition to the management and the supervisory board, family members of the business owners often found employment in other positions. Such a situation occurred in $83 \%$ of the surveyed enterprises $(n=270)$. The purpose of family businesses was therefore also to create jobs for the family.

In the surveyed family enterprises, a strong influence of the owner's family on the current and development activity of the enterprise was observed. This concerned both general strategic decisions and also those relating to financing and investment policy. To a lesser extent, the owners' families were largely involved in making operational decisions in the field of management (Table 8).

Table 8. The influence of the owners' family on selected areas of the company's activity $(\mathrm{n}=392)$

\begin{tabular}{|l|c|c|c|c|}
\hline \multirow{2}{*}{\multicolumn{1}{|c|}{ Type of decision }} & \multicolumn{3}{c|}{ The power of influence (answers in \%) } \\
\cline { 2 - 5 } & Very high & High & Medium & Small \\
\hline 1. Strategic decisions & 81.6 & 11.8 & 5.1 & 0.5 \\
\hline 2. Investment policy & 77.3 & 16.3 & 4.3 & 1.0 \\
\hline 3. Strategic financing decisions & 75.5 & 14.8 & 7.7 & 1.0 \\
\hline 4. Operational financing decisions & 69.0 & 17.4 & 10.0 & 1.8 \\
\hline
\end{tabular}

Source: Author's own study based on the results of the survey.

In accordance with the definition adopted in this article that the family-owned nature of the enterprise is determined by the family's participation in ownership, the board of directors and supervisory bodies, the surveyed companies are classified based on these criteria. The application of cluster analysis indicated the occurrence of four types of family businesses (see Table 9). Post-hoc statistic verification of mean differences for the performed classifications was carried out using the Games-Howell tests (no constancy of variance) (Keselman \& Rogan, 1978). The results of the verification are presented in Tables 10 and 11 (Annex). Due to the low family share in ownership in group 4, it was omitted in further analysis. Other companies formed the following groups:

1) enterprises with a large share of the family in property, in the board and in the supervisory bodies,

2) enterprises with a large share of the family in property, low management board participation and quite large in supervisory bodies, and

3) enterprises with a large share of the family in ownership, quite a lot of participation in the board and very little in the supervisory bodies. 
Pobrane z czasopisma Annales $\mathrm{H}$ - Oeconomia http://oeconomia.annales.umcs.pl

Data: 26/04/2023 14:01:45

THE ROLE OF THE FAMILY IN POLISH FAMILY ENTERPRISES

Table 9. Groups of family enterprises in the studied population

\begin{tabular}{|l|c|c|c|c|}
\hline \multirow{2}{*}{ Criterion } & \multicolumn{4}{|c|}{ Groups of enterprises } \\
\cline { 2 - 5 } & Group 1 $(\mathrm{n}=34)$ & Group 2 $(\mathrm{n}=16)$ & Group 3 $(\mathrm{n}=306)$ & Group 4 (n=10) \\
\hline Family participation among the owners & 0.91 & 0.94 & 0.97 & 0.32 \\
\hline Family participation in the board & 0.95 & 0.16 & 0.86 & 0.92 \\
\hline Family participation in supervisory bodies & 0.90 & 0.79 & 0.02 & 0.22 \\
\hline
\end{tabular}

Source: Author's own study based on the results of the survey.

In graphical terms, Figure 1 shows the groups of family enterprises identified based on the analysis.

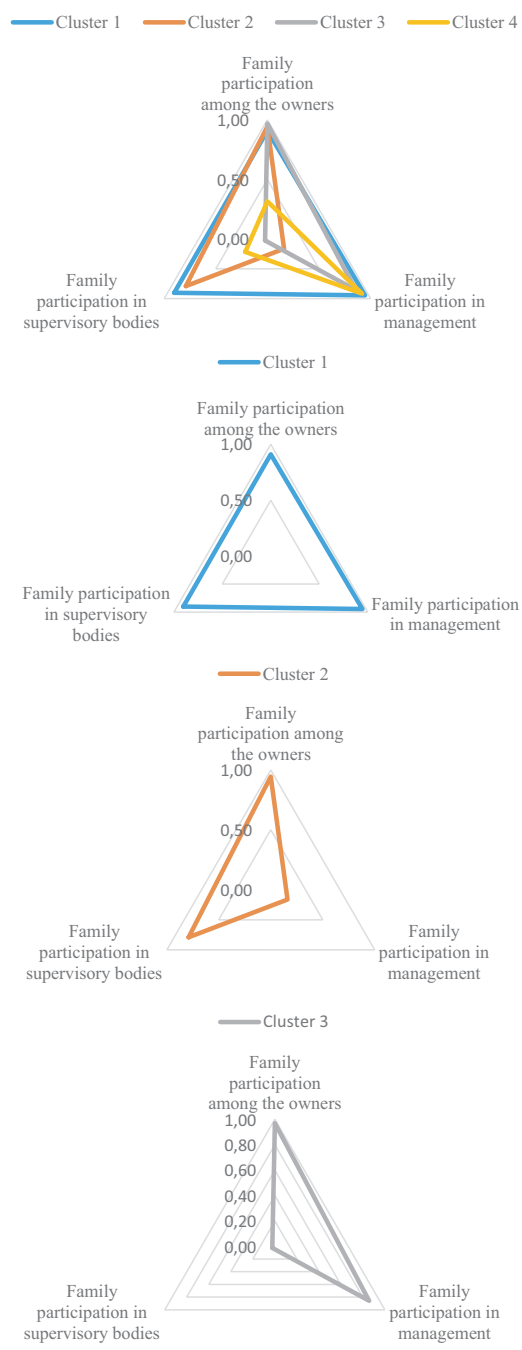

Figure 1. Groups of family enterprises 


\section{Conclusions}

The research allowed drawing the following conclusions on the role of the family in Polish family enterprises.

1. In the majority of family enterprises, the family of owners owns a dominant share in equity. This is undoubtedly related to the relatively short period of existence of this type of enterprise in Poland. Most of them are in the ownership of the first generation, and the share of non-family owners is small. The first hypothesis was positively verified.

2. A significant part of family businesses is financed only with equity and fully accumulated profits. This indicates that the owners attach importance to maintaining financial independence from third parties.

3 . The boards of family enterprises are dominated by people from the first generation of their founders. In most enterprises, they are very narrow (one to two people), which proves the desire to maintain strong direct control over the company. A person from the family of owners is usually the chairman of the board. Only decision-making functions in the field of finance are relatively more often given to specialists from outside the family circle. Such test results mean positive verification of the second hypothesis.

4. Supervisory bodies are appointed voluntarily (except for joint-stock companies) in relatively few enterprises. They often consist of a small group of people, many of whom are members of the owner's family. This solution is favourable to the exercise of disciplinary functions in relationship to the management of the enterprise. This is undoubtedly related to the previously indicated large family share in the management of enterprises. Thus, the third hypothesis was also verified positively.

The obtained results are to a large extent confirmed by other studies conducted in Poland. They indicate that in $92 \%$ of family enterprises, the family had more than a $50 \%$ share in capital, family members of the owners most often deal with direct management at the same time, and if even in the enterprises the transfer of power took place, it was not always accompanied by the transfer of the management to the next generation (Firma ..., 2016). Thus, the dominant type in Poland is the family enterprise with a strong link in terms of ownership and management with the family, which was also found in other studies (Sobiecki (Ed.), 2014).

The family enterprise, and in particular its ownership structure and management system, are subject to change. The relatively short period of existence of family enterprises in Poland means that the activity of many of them is based on simple solutions typical for the first phase of enterprise development. This is indicated by a strong concentration of property in the hands of the family and a narrow circle of co-owners. This translates into power structures in the enterprise. The management boards of enterprises are quite narrow, and the family members dominate in them. The main owner often directly manages the company as the chairman of the board. 
Supervisory boards are appointed in few enterprises. Enterprises are often treated as a place of employment for family members who are also in positions that are not related to managing them.

On the other hand, it should be taken into account that the majority of the surveyed enterprises were companies with fairly small employment and revenues. The complexity of their activities was therefore relatively small and did not require the creation of extensive corporate governance structures.

\section{References}

Achleitner, A.-K., Schraml, S.C., \& Klöckner, O. (2008). Wie professionell ist die Unternehmensfinanzierung tatsächlich? München: Center for Entrepreneurial and Financial Studies, Technische Universität München, AlphaZirkel und Droege \& Comp. Financial Advisors.

Achleitner, A.-K., Bock, C., Braun, R., Schraml, S., \& Welter, J. (2010). Ausgewählte Aspekte der Vorstandsvergütung in börsennotierten Unternehmen: Familien- vs. Nicht-Familienunternehmen. Zeitschrift für Corporate Governance, 58(3), 227-258.

Anteile der Familienunternehmen in Deutschland an allen Unternehmen, an der Gesamtbeschäftigung und am gesamten Umsatz. (2018). Retrieved from https://de.statista.com/statistik/daten/studie/234891/.

Aronoff, C.E., \& Ward, J.L. (2011). Family Business Values: How To Assure a Legacy of Continuity and Success. New York, NY: Palgrave Macmillan.

Astrachan, J.H., \& Jaskiewicz, P. (2008). Emotional Returns and Emotional Costs in Privately Held Family Businesses: Advancing Traditional Business Valuation. Family Business Review, 21(2), 139-149.

Astrachan, J.H., Klein, S.B., \& Smyrnios, K.X. (2002). The F-PEC Scale of Family Influence: A Proposal for Solving the Family Business Definition Dilemma. Family Business Review, 15(1), 45-58.

Astrachan, J.H., \& Shanker, M.C. (2003). Family Businesses' Contribution to the U.S. Economy: A Closer Look. Family Business Review, 16(3), 211-216.

Commission Recommendation 2003/361/EC of 6 May 2003 concerning the definition of micro, small and medium-sized enterprises. (2003). OJ L 124 of 20.5.2003.

De Visscher, F.M. (2004). Balancing Capital, Liquidity and Control. Families in Business, 16, 45-47.

Donnelley, R.G. (2002). The Family Business. In C.E. Aronoff, J.H. Astrachan, \& J.L. Ward (Eds.), Family Business Sourcebook. Georgia: Family Enterprise Publishers.

Familienunternehmen in Österreich. Status quo 2013. (2013). Wien: KMU Forschung Austria.

Firma rodzinna to marka. (2016). Raport, Poznań: Instytut Biznesu Rodzinnego.

Gersick, K.E., McCollom Hampton, M., \& Lansberg, I. (1997). Generation to Generation Life Cycles of the Family Business. Boston, MA: Harvard Business School Press.

Hartley, B.B., \& Griffith, G. (2009). Family Wealth Transition Planning. Advising Families with Small Businesses. New York, NY: Bloomberg Press.

Hennerkes, B.-H. (1998). Familienunternehmen sichern und optimieren. Frankfurt am Main: Campus Verlag.

Hepperle, T. (2011). Stiftungen als Instrumente zur Lösung von Schnittstellenkonflikten in Familienunternehmen. Lohmar-Köln: Josef Eul Verlag.

Hiebl, M.R.W. (2012). Die Rolle des Chief Financial Officer in großen Familienunternehmen. Berlin: Epubli GmbH.

Kenyon-Rouvinez, D., \& Ward J.L. (2005). Family Business Key Issues. London: Palgrave Macmillan.

Keselman, H., \& Rogan, J. (1978). A Comparison of the Modified-Tukey and Scheffe Methods of Multiple Comparison for Pairwise Contrasts. Journal of the American Statistical Association, 73(361), 47-52.

Klein, S.B. (2000). Family Businesses in Germany: Significance and Structure. Family Business Review, 13(3), 157-173. 
Klein, S.B. (2010). Familienunternehmen. Theoretische und empirische Grundlagen. Lohmar-Köln: Josef Eul Verlag.

Koładkiewicz, I. (2015). System nadzoru w firmie rodzinnej. Doświadczenia polskie i światowe. Warszawa: Wydawnictwo Poltext.

Mandl, I. (2008). Overview of Family Business Relevant Issues. Final report, Vienna: Austrian Institute for SME Research.

Mutter, Ch. (2011). Vermögensmanagement für Familienunternehmer. Stuttgart: Schäffer-Poeschel Verlag. Overview of Family Business Relevant Issues: Research, Networks, Policy Measures and Existing Studies. (2009). Final Report of the Expert Group, European Commission, November.

Pernsteiner, H., \& Węcławski, J. (Eds.) (2016). Finanzierung und Corporate Governance von polnischen Familienunternehmen. Linz: Trauner Verlag.

Pieper, T., \& Klein, S.B. (2007). The Bulleye: A Systems Approach to Modeling Family Firms. Family Business Review, 20(4), 301-319.

Poza, E. (2010). Family Business. Mason, OH: South-Western Cengage Learning.

Prym, Ch. (2011). Familienunternehmen und Beteiligungskapital. Lohmar-Köln: Josef Eul Verlag.

Scherer, S., Blanc, M., Kormann, H., Groth, T., \& Wimmer R. (2012). Familienunternehmen. Erfolgsstrategien zur Unternehmenssicherung. Frankfurt am Main: Deutscher Fachverlag.

Schweinsberg, K., \& Koenen, L.M. (2010). Fremdmanagement in Familienunternehmen. Bonn: INTES Verlag.

Simon, F.B., Wimmer, R., \& Groth, T. (2005). Mehr-Generationen-Familienunternehmen. Heidelberg: Carl-Auer Verlag.

Simon, F.B. (Ed.) (2011). Die Familie des Familienunternehmens. Ein System zwischen Gefühl und Geschäft. Heidelberg: Carl-Auer Verlag.

Sirmon, D.G., \& Hitt, M.A. (2003). Managing Resources: Linking Unique Resources, Management, and Wealth Creation in Family Firms. Entrepreneurship Theory and Practice, 27(4), 339-358.

Sobiecki, R. (Ed.) (2014). Przedsiębiorstwo rodzinne w gospodarce globalnej. Warszawa: Oficyna Wydawnicza SGH.

Sten, J. (2006). Transfers of Family Business to Non-Family Buyers. The Selling Business Family Perspective. Helsinki: Helsingsfors.

Ustawa z dnia 15 września 2000 r. Kodeks spółek handlowych, Dz.U. 2000 Nr 94 poz. 1037 (The Act of 15 September 2000 Code of Commercial Companies, Journal of Laws of 2000, No. 94, item 1037).

Wiechers, R. (2006). Familienmanagement zwischen Unternehmen und Familie. Heidelberg: Carl-Auer Verlag.

Wimmer, R., Domayer, E., Oswald, M., \& Vater, G. (2018). Familienunternehmen Auslaufmodell oder Erfolgstyp? Wiesbaden: Springer, Gabler Verlag.

Winkeljohann, N., \& Kellersmann, D. (2008). Fremdmanagement in Familienunternehmen. Vor- und Nachteile: Ergebnisse einer empirischen Studie. Zeitschrift für Corporate Governance, 6, 253-260.

Zellweger, T., Halter, F., \& Frey, U. (2006). Financial Performance of Privately Held Family Firms, Center for Family Business. St. Gallen: University of St. Gallen. 
Pobrane z czasopisma Annales H - Oeconomia http://oeconomia.annales.umcs.pl

Data: 26/04/2023 14:01:45

THE ROLE OF THE FAMILY IN POLISH FAMILY ENTERPRISES

\section{Appendix}

Table 10. Analysis of variance for groups of family enterprises

\begin{tabular}{|l|c|c|c|c|c|}
\hline \multirow{2}{*}{ Indicator } & \multicolumn{2}{c|}{ Focus } & \multicolumn{2}{c|}{ Error } & \multirow{2}{*}{ F } \\
\cline { 2 - 6 } & Average square & df & Average square & df & \\
\hline Family participation among the owners & 1.389 & 3 & 0.013 & 362 & 108.885 \\
\hline Family participation in management & 2.633 & 3 & 0.052 & 362 & 51.090 \\
\hline Family participation in supervisory bodies & 10.267 & 3 & 0.013 & 362 & 819.655 \\
\hline
\end{tabular}

Source: Author's own study based on the results of the survey.

Table 11. Multiple comparison for groups of family enterprises

\begin{tabular}{|c|c|c|c|c|c|c|c|}
\hline \multicolumn{4}{|c|}{ Dependent variable } & \multirow{2}{*}{$\begin{array}{c}\text { Medium } \\
\text { difference (I-J) }\end{array}$} & \multirow{2}{*}{$\begin{array}{c}\begin{array}{c}\text { Standard } \\
\text { error }\end{array} \\
0.0445\end{array}$} & \multirow{2}{*}{$\begin{array}{c}\text { The } \\
\text { significance }\end{array}$} & \multirow{2}{*}{ 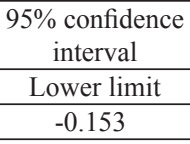 } \\
\hline \multirow{12}{*}{$\begin{array}{l}\text { Family } \\
\text { participation } \\
\text { among the } \\
\text { owners }\end{array}$} & \multirow{12}{*}{$\begin{array}{l}\text { Games-Howell } \\
\text { test }\end{array}$} & \multirow{3}{*}{1} & 2 & & & & \\
\hline & & & 3 & -0.0586 & 0.0327 & 0.295 & -0.147 \\
\hline & & & 4 & $.5940^{*}$ & 0.0835 & 0.000 & 0.347 \\
\hline & & \multirow{3}{*}{2} & 1 & 0.0339 & 0.0445 & 0.872 & -0.085 \\
\hline & & & 3 & -0.0247 & 0.0311 & 0.856 & -0.114 \\
\hline & & & 4 & $.6279^{*}$ & 0.0829 & 0.000 & 0.381 \\
\hline & & \multirow{3}{*}{3} & 1 & 0.0586 & 0.0327 & 0.295 & -0.030 \\
\hline & & & 2 & 0.0247 & 0.0311 & 0.856 & -0.064 \\
\hline & & & 4 & $.6526^{*}$ & 0.0772 & 0.000 & 0.412 \\
\hline & & \multirow{3}{*}{4} & 1 & $-.5940^{*}$ & 0.0835 & 0.000 & -0.841 \\
\hline & & & 2 & $-.6279^{*}$ & 0.0829 & 0.000 & -0.874 \\
\hline & & & 3 & $-.6526^{*}$ & 0.0772 & 0.000 & -0.893 \\
\hline \multirow{12}{*}{$\begin{array}{l}\text { Family } \\
\text { participation } \\
\text { in manage- } \\
\text { ment }\end{array}$} & \multirow{12}{*}{$\begin{array}{l}\text { Games-Howell } \\
\text { test }\end{array}$} & \multirow{3}{*}{1} & 2 & $.7850^{*}$ & 0.0571 & 0.000 & 0.626 \\
\hline & & & 3 & $.0891^{*}$ & 0.0267 & 0.008 & 0.018 \\
\hline & & & 4 & 0.0294 & 0.0614 & 0.962 & -0.153 \\
\hline & & \multirow{3}{*}{2} & 1 & $-.7850^{*}$ & 0.0571 & 0.000 & -0.944 \\
\hline & & & 3 & $-.6959^{*}$ & 0.0539 & 0.000 & -0.849 \\
\hline & & & 4 & $-.7556^{*}$ & 0.0772 & 0.000 & -0.971 \\
\hline & & \multirow{3}{*}{3} & 1 & $-.0891^{*}$ & 0.0267 & 0.008 & -0.160 \\
\hline & & & 2 & $.6959^{*}$ & 0.0539 & 0.000 & 0.543 \\
\hline & & & 4 & -0.0597 & 0.0585 & 0.742 & -0.239 \\
\hline & & \multirow{3}{*}{4} & 1 & -0.0294 & 0.0614 & 0.962 & -0.212 \\
\hline & & & 2 & $.7556^{*}$ & 0.0772 & 0.000 & 0.541 \\
\hline & & & 3 & 0.0597 & 0.0585 & 0.742 & -0.119 \\
\hline \multirow{12}{*}{$\begin{array}{l}\text { Family } \\
\text { participation } \\
\text { in superviso- } \\
\text { ry bodies }\end{array}$} & \multirow{12}{*}{$\begin{array}{l}\text { Games-Howell } \\
\text { test }\end{array}$} & \multirow{3}{*}{1} & 2 & 0.1123 & 0.0586 & 0.248 & -0.049 \\
\hline & & & 3 & $.8799^{*}$ & 0.0283 & 0.000 & 0.804 \\
\hline & & & 4 & $.6879^{*}$ & 0.0911 & 0.000 & 0.413 \\
\hline & & \multirow{3}{*}{2} & 1 & -0.1123 & 0.0586 & 0.248 & -0.274 \\
\hline & & & 3 & $.7676^{*}$ & 0.0518 & 0.000 & 0.619 \\
\hline & & & 4 & $.5756^{*}$ & 0.1009 & 0.000 & 0.286 \\
\hline & & \multirow{3}{*}{3} & 1 & $-.8799^{*}$ & 0.0283 & 0.000 & -0.956 \\
\hline & & & 2 & $-.7676^{*}$ & 0.0518 & 0.000 & -0.917 \\
\hline & & & 4 & -0.1920 & 0.0869 & 0.192 & -0.463 \\
\hline & & \multirow{3}{*}{4} & 1 & $-.6879^{*}$ & 0.0911 & 0.000 & -0.962 \\
\hline & & & 2 & $-.5756^{*}$ & 0.1009 & 0.000 & -0.866 \\
\hline & & & 3 & 0.1920 & 0.0869 & 0.192 & -0.079 \\
\hline
\end{tabular}

* represent statistical significance at the $5 \%$ level

Source: Author's own study based on the results of the survey. 